\title{
Evaluation of body postures of Belgian Malinois dogs during a police dog training in Germany"
}

\author{
Yasemin SALGIRLI DEMIRBAS \\ Ankara University, Faculty of Veterinary Medicine, Department of Physiology, Ankara, Turkey.
}

\begin{abstract}
Summary: Police dog training is a strict training with high level of arousal and stress. In the present study, it was aimed to investigate behavioral tendency to exhibit submissive body posture in Belgian Malinois dogs while performing routine obedience exercises in police dog training. Furthermore, factors causing different body postures in those dogs were evaluated. Accordingly, 6 of the 42 dogs $(14,3 \%)$ were assessed as dogs having neutral - confident body postures during the obedience exercises. Rest of the dogs $(85,7 \%)$, however, exhibited at least one behavioral element of submission. No statistically significant correlations were found between age and submissive body posture, gender and submissive body posture as well as between real criminal contact and submissive body posture. The results obtained in this study show that dogs of the breed, Belgian Malinois are more likely to show submissive behavior than other behaviors such as neutral or attentive behavior in a training condition with high level of arousal and stress.
\end{abstract}

Key words: Police dog, body posture, submission, Belgian Malinois.

\section{Belçika Malinois köpeklerinin vücut pozisyonlarının Almanya'daki polis köpeği eğitimi sırasında değerlendirilmesi}

Özet: Polis köpeği eğitimi, yüksek uyarılma ve stres seviyesi içeren katı bir eğitimdir. Bu çalışmada, Belçika Malinois köpeklerinin polis köpeği eğitiminde, itaat egzersizleri sırasında teslimiyetçi vücut dili sergileme yönündeki davranışsal eğilimlerinin incelenmesi amaçlanmıştır. Ayrıca, bu köpeklerde değişik vücut pozisyonlarına neden olan faktörler de değerlendirilmiştir. Sonuç olarak itaat egzersizleri sırasında, 42 köpeğin 6's1 (\%14,3) normal - kendine güvenli vücut pozisyonuna sahip olarak değerlendirilmiştir. Bununla birlikte, diğer köpekler (\% 85,7) teslimiyet davranışına ait en az bir davranış unsurunu sergilemişlerdir. Yaş ve teslimiyetçi vücut dili, cinsiyet ve teslimiyetçi vücut dili ve gerçek bir suçluyla karşılaşmış olma ve teslimiyetçi vücut dili arasında istatistiksel olarak anlamlı bir korelasyon bulunmamıştır. Bu araştırmadan elde edilen sonuçlar Belçika Malinois ırkına ait köpeklerin uyarılma ve stres seviyesi yüksek eğitim koşullarında nötral davranış veya dikkat davranışından ziyade teslimiyetçi davranış göstermeye daha yatkın olduklarını göstermiştir.

Anahtar sözcükler: Polis köpeği, vücut pozisyonu, teslimiyet, Belçika Malinois.

\section{Introduction}

Dogs have been selectively bred for thousands of years in order to improve specific behavioral and phenotypic features. This has resulted in a great variety of characters in dogs in terms of appearance and behavior. Nowadays, more than 400 dog breeds exist, most of which has a certain task such as hunting, herding, retrieving etc. Until recently, Belgian Malinois (BM) and German Shepherd Dogs (GSD) have been two of most commonly used dog breeds in police work (5). However, BM, which has normally been bred for different tasks such as herding, guarding and flock protecting (15) is lately preferred over GSD as police service dogs mainly because GSD predisposes to a number of inherited disorders (1). One of the reasons of using BM as police service dogs is his strong willingness to work and intelligence, as they have been selectively bred for their high reactivity and responsiveness to the commands (15).

According to Feddersen-Petersen and Ohl (6), neutral body posture of the dog can be defined as follows: "Body orientation of the dog must be parallel to the ground as the legs are held in a normal straight position. One may also notice the slightly raised head, noise oriented-ears and smooth facial expression (this characteristic depends on the dog breed). The dog holds his tail downwards in a relaxed position when exhibiting a neutral body posture". Behavioral elements of submission,

\footnotetext{
This article is based on a dissertation titled "Comparison of Stress and Learning Effects of Three Different Training Methods: Electronic Training Collar, Pinch Collar and Quitting Signal”.
} 
however, are slightly different from those of neutral postures. In a dog exhibiting submission, body posture is crooked and slightly crouched. Ears are lowered while directing backwards or flattened on the head. The lips are pulled back horizontally while covering the teeth. This facial expression is also named as submissive grin (7). Corners of the eyes are also pulled back as a result of tense facial muscles. In addition to that, tail is held in a lowered position, even between the legs, and it may be wagged or held still. Rolling over is exhibited by the dog which shows ultimate submission, so that the abdomen, only vital part that lacks bony protection, is exhibited. In this case, submissive urination can also be observed (2, $7,14,16)$.

The main aim of the present study was to evaluate body postures of $\mathrm{BM}$ police dogs during routine obedience exercises. Thus, tendency to submissive body language in those breed of dogs while performing routine obedience exercises during police dog training was assessed. Furthermore, we intended to determine the factors causing different body postures in these dogs. Therefore, correlations were sought between the age and the submissive body postures, between the gender and the submissive body postures well as between the real criminal contact and the submissive body postures.

This is the first research effort to evaluate body postures of BM dogs, which are the most commonly used police service dogs all over the world, in a police dog training.

\section{Materials and Methods}

Subjects: Forty-two adult police dogs of both genders (33 males and 9 females) and varying ages (3-10 years old) of the breed Belgian Malinois served as subjects for this study. Dogs were divided into three groups, i.e. young (under 2 years old), middle-aged (2-5 years old) and old-aged (over 5 years old) dogs, according to their age (8). All dogs in the study were official police service dogs and recruited from two different police departments in Germany. During the study, dogs participated the sessions with its own handler. All subjects could be clearly identified with a permanent mark (microchip or ear tattoo).

Questionnaire: A questionnaire with three different sections was addressed to the canine officers who participated in this research as handlers. The first section of the questionnaire (general information) was designed to gather information regarding the dogs' demographic data and past experience. In the second part (training aids), questions related to dogs' past experiences with the training aids and former and/or current behavioral problems of the dogs were asked. The last part (general assessment) contained the questions about individual characteristics of the dogs such as self-confidence, arousal level and motivation type. The aim of using this questionnaire as a part of this study was to gain information about dogs' characteristics, past experience, health situation etc., and thus, to avoid incorrect assessment of the results. Furthermore, through this information, correlations between those parameters and body languages of the dogs were possible to be evaluated.

Test Persons: Two test instructors were present during the entire experiment. The main responsibility of test instructors was the observation and control of the test sessions. Besides, one of the test instructors gave the starting and ending instructions of obedience sessions while the second instructor was filming the experiment.

Test Area: Three different training grounds were used as test areas. All test areas were already used as training grounds for the police dog training. Thus, all of the dogs were familiar with the area where they were tested.

Experiment: The dogs were brought to the training area with a leash on standard collar and were kept on the leash throughout the entire experiment. In the obedience session, the dog and the handler performed some standard obedience exercises for 80 seconds. During this session, the owner gave commands such as sit, heel, down, stay and come and was not allowed to correct the dog if the dog made any mistakes. Thus, the general body posture of the dog as well as the reaction of the dog to the commands given by its handler during obedience training could be observed and analyzed. The entire experiment was filmed on DVDs using a video camera. The recorded DVDs were reviewed later in order to analyze the body language of the dogs during the obedience sessions. Considering the relevant literature $(13,18,20)$, focal animal sampling was used as sampling method and instantaneous sampling was used as recording method in order to evaluate body postures of the dogs during the obedience sessions. To this end, each obedience session was divided into 10 sample intervals each of which lasted 8 seconds. At the end of each sample interval the video was paused and the positions of separate body parts have been analyzed by using an extensive ethogram, which was designed following the studies of Feddersen-Petersen and Ohl (6), Beerda (3), and Schilder and van der Borg (17). Definitions of bodily expressions are shown in table 1.

Analyses: Data analysis was performed with SPSS 16.0 Inc. software. Kruskal-Wallis tests were used for the comparison of group differences in body positions during the obedience sessions. In order to determine the general body position of the dogs during the obedience session, frequency analyses were performed. Two significancy levels were set at the levels $95 \%\left(\mathrm{p}<0,05^{* *}\right)$ and $99 \%$ $\left(\mathrm{p}<0,01^{*}\right)$.

Ethical approval was given to this research by County Government. 
Table 1. Descriptions of bodily expressions.

Tablo 1. Vücut ifadelerinin açıklamaları.

\begin{tabular}{|c|c|}
\hline Body parts & Descriptions \\
\hline \multicolumn{2}{|l|}{ Facial Expression } \\
\hline Corner of the mouth relax & Lips in normal position \\
\hline Corner of the mouth back & Lips drawn back \\
\hline Corner of the mouth forward & Lips are forming " $\mathrm{C}$ ", short and round shape \\
\hline Submissive grin & Lips drawn back to expose teeth \\
\hline \multicolumn{2}{|l|}{ Head position } \\
\hline Neutral & Head held in a normal and a relaxed position \\
\hline Elevated & Head lifted up to form a wide angle with the neck \\
\hline Trained eye contact & Keeping eye contact with the owner \\
\hline Slightly lowered & The head is held in low position to a small extent \\
\hline Lowered & The head is held in a low position \\
\hline Turned away & The head is turned away from the owner \\
\hline \multicolumn{2}{|l|}{ Ears position } \\
\hline Neutral & $\begin{array}{l}\text { The pinnae are held partly sidewards and completely upwards; opening is completely visible } \\
\text { from the side }\end{array}$ \\
\hline Maximally backwards & The pinnae are flat on the head \\
\hline Backwards & $\begin{array}{l}\text { The pinnae are backwards for more than half, are upright of buckled, they are in one line with } \\
\text { the stop of the nose and are not flat on the head }\end{array}$ \\
\hline Laterally turned & The pinnae are turned sidewards; opening is not visible from the side \\
\hline High & The openings point forward while ears held in an aroused position \\
\hline Directed to the stimuli/owner & $\begin{array}{l}\text { Each pinnae are directed to source of the stimuli by establishing different combinations of ear } \\
\text { positions }\end{array}$ \\
\hline \multicolumn{2}{|l|}{ Tail position } \\
\hline Neutral & The breed specific tail position under neutral conditions \\
\hline Half low & Tail lower than neutral \\
\hline Low & Upper side of tail against back, tail forms a "S", \\
\hline Curled between legs & Tail held stabile between the legs \\
\hline Straight out & Tail follows line of lower back of dog \\
\hline High & Tail higher than neutral \\
\hline \multicolumn{2}{|l|}{ Body posture/ Joints } \\
\hline High posture & $\begin{array}{l}\text { The breed specific posture as shown by dogs under neutral conditions, but in addition the tail } \\
\text { is positioned higher or the position of the head is elevated and the ears are pointed forwards }\end{array}$ \\
\hline Neutral posture & The breed posture shown by dogs under neutral conditions \\
\hline Half low posture & $\begin{array}{l}\text { From three features: a lowered position of the tail (compared to the neutral posture), a } \\
\text { backward position of the ears and bent legs, two are exhibited }\end{array}$ \\
\hline Low posture & The position of the tail is lowered, the ears are positioned backwards and the legs are bent \\
\hline Very low posture & Low posture, but now the tail is curled forward between the hind legs \\
\hline The back is arched & Curving position of the back \\
\hline Extremely ness & The back is arched maximum together with lowering of the head \\
\hline Lowering back & Flexed hind legs \\
\hline Crouching & Flexed fore- and hind legs \\
\hline
\end{tabular}

\section{Results}

Behavioral evaluation: In order to assess submissive body posture, separate ear (low ear), head (low head), tail positions (low tail) and, also, the behavioral elements such as flexing of the joints, arching of the back and extreme ness of body posture were scored (Figure 1). All in all, when the dog exhibited at least two submissive behavioral elements during the obedience session, body postures of the dogs were scored as submissive body posture.

Overall, 36 dogs $(85,7 \%)$ were evaluated as the dogs exhibited at least one behavioral element of submission during the experiment. Eleven dogs (26, 2 \%) were evaluated as the dogs which showed submissive 


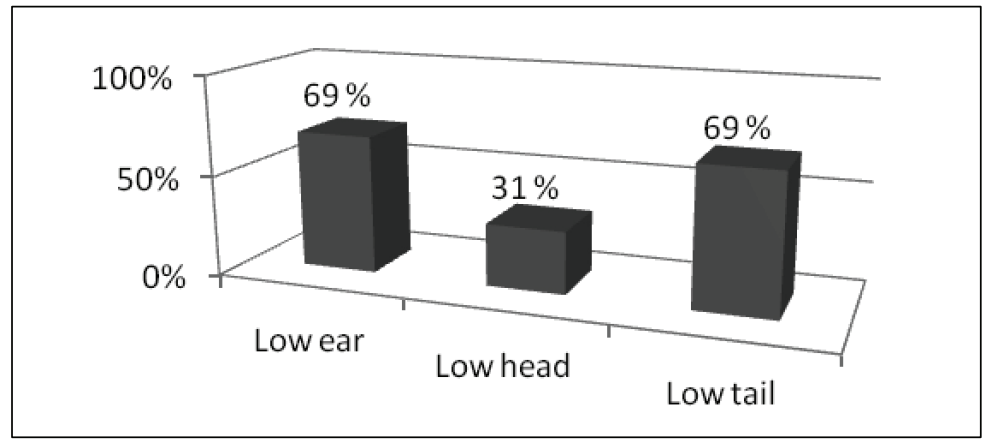

Figure 1. Percentage of the dogs of showing elements of submissive body posture.

Şekil 1. Teslimiyetçi vücut dili unsurlarını sergileyen köpeklerin yüzdesi.

body posture since they exhibited at least two submissive behavioral elements together during the experiment. It was also observed that 3 dogs exhibited stress related behaviors such as flexing of the joints, shaking of the head, whining and barking together with the commands. Six dogs $(14,3 \%)$ were evaluated as the dogs which had -neutral-confident body postures in the study.

General information: No statistically significant correlations were found between the age and the submissive body posture $(p=0,758)$, the gender and the submissive body posture $(\mathrm{p}=0,931)$ as well as between the real criminal contact and the submissive body posture $(\mathrm{p}=0,931)$.

Considering the answers given by the dog handlers to this questionnaire, a summary table containing following descriptions was established (Table 2):

Table 2. Summary table of characteristics.

Tablo 2. Özelliklere ait özet tablosu.

\begin{tabular}{lc}
\hline Characteristics & $\begin{array}{c}\text { \% } \\
\text { (frequency of } \\
\text { the dogs) }\end{array}$ \\
\hline Gender & \\
Male & 78,6 \\
Female & 21,4 \\
Age & \\
Under 2 years old & 0 \\
2-5 years old & 66,7 \\
Over 5 years old & 33,3 \\
Real criminal contact & \\
Yes & 74,3 \\
No & 25,7 \\
Level of arousal & \\
High in training & 76,2 \\
Always high & 19 \\
Always relax & 4,8 \\
Behavioral problem & \\
Yes & 42,8 \\
No & 57,2 \\
Currently Available Behavioral problem & \\
Barking & 55,1 \\
Unwanted hunting behavior & 13,8 \\
Displacement activities & 10,3 \\
Stereotype & 10,3 \\
Others & 10,3 \\
Self-confidency & \\
Self-confident against human & 85,7 \\
Self-confident against environment & 92,9 \\
\hline
\end{tabular}

\section{Discussion and Conclusion}

In this study, it was aimed to evaluate body language of BM dogs during routine police dog training and, thus, to assess whether this breed of dogs show submissive body posture, which is a sign of stress and nervousness in dogs, in a strict training situation. Police dog training is a strict and rigid training which requires high level of arousal and motivation. Many things should be accomplished in relatively short time in which an effective handler and dog partnership must also be built. Dogs must unconditionally pay attention to its handler and obey commands without any hesitation during the training (4). Nowadays, police service dogs are being used worldwide in different areas such as evidence detection, tracking, narcotic detection, explosive detection, human remains detection etc. Since even the slightest mistake during the training may cause a significant loss in real life, police dog training is a kind of training putting a significant amount of stress on the dog as well as on his handler. Therefore, dogs used as police dogs come from specific breeding lines, which are ranked high in personality traits such as "'aggressiveness"' and "playfulness"' (17, 21). However, it is also emphasized that selecting a dog for one limited trait such as high energy may cause a behavior which is counter protective for police work. Thus, it is significant to choose a dog which is balanced in personality traits such as sociability, playfulness, search and aggressive behavior (4). Nowadays, BM is one of the most commonly used dog breed in police departments in most of the countries (5).

There were two main reasons for choosing police dogs for this experiment: The first reason of using police dogs was to be able to test as many dogs as possible. Since the breed of BM is commonly used police dogs, it was easy to reach these dogs from police departments. The second reason was since police dogs are kept and trained in a similar way, it was possible to minimize the variability arising from housing and training conditions.

As a result, only 6 of the 42 dogs $(14,3 \%)$ were evaluated as the dogs which had -neutral-confident body posture during obedience exercises. Rest of the dogs, on 
the other hand, exhibited at least one behavioral element of submissive behavior. Most of the dog handlers (92, $9 \%$ ), however, reported that their dogs are confident against environment. Although the results seem to contradict each other, they are consistent with the idea that features such as strong desire and high motivation to work as well as sensitiveness may cause certain amount of nervousness in dogs in some situations (9). Accordingly, it may be suggested that dogs of the breed $\mathrm{BM}$ are more likely to show submissive behavior than other behaviors such as neutral or attentive behavior in a training condition with high level of arousal since they are not a breed of dog which easily copes with stress.

A number of different researches reported that rapidly acting stress mediators such as noradrenaline and corticosterone improve learning $(10,11,19)$. Thus, it can also be proposed that sensitivity to stress and low frustration threshold in BM may be a factor which enhances their learning ability as they show high intelligence in a training situation requiring learning of complex actions (9).

This raises an important question whether this context dependent nervousness is affected by other factors such as age, gender and history of confronting with a real criminal. However, no statistically significant correlations were found between those parameters.

Within the frame of the study, it was also set out to investigate the tendency in BM police dogs to develop behavioral disorders. Accordingly, dogs having currently available behavioral problems were assessed as $42,8 \%$ of the dogs. This seemingly high ratio may also support the idea that BM is sensitive to stress and frustration.

With respect to these findings, it can be suggested that $\mathrm{BM}$ is a breed of dog which can show behavioral elements of submission under strict training conditions although it is a confident dog in nature. Within the frame of the present study no detailed investigation on relationship between the $\operatorname{dog}$ and his handler was conducted. Therefore, it is not yet known whether there is a correlation between dog handler-dog relationship and body language of BM dogs as stated by Lefebvre (12). In the future, research evaluating influence of the handler and the dog relationship on behavior of the dog during a police dog training could likely help answering this question. Further studies are needed to demonstrate the context dependent nervousness in BM using a standardised temperament test.

\section{References}

1. Asher L, Diesel G, Summers JF, McGreevy PD, Collins LM (2009): Inherited defects in pedigree dogs. Part 1: Disorders related to breed standards. Veterinary Journal. 182(3): 402-411.
2. Beaver B (1999): Canine behaviour: a guide for veterinarians. Saunders Company, Philadelphia.

3. Beerda B (1997): Stress and well-beings in dogs. Dissertation, Utrecht, Netherlands.

4. Bryson S (2002): Effects of genetic selection and experience on police dog behavior. http://www.uspcak9.com/training/K9BehArticle.pdf.

5. Emert PR (1985): Law enforcement dogs. Ed: Schroeder $H$. Crestwood House. New York.

6. Feddersen-Petersen D, Ohl F (1995): Ausdrucksverhalten beim Hund. Gustav Fischer Verlag, Jena, Stuttgart

7. Fox MW (1971): The comparative ethology of the domesticated dog. In: M. W. FOX: Behaviour of wolves, dogs and related canids. Cape, London.

8. Goff BL, Roth JA, Arp LH, Incefy GS (1987): Growth hormone treatment stimulates thymulin production in aged dogs. Clinical \& Experimental Immunology, 68, 580-587.

9. Hadžimujagić $\boldsymbol{N}$ (2010): Effects of inadequate care for mine detection dogs on MDD performance quality in mine action activities. International Symposium "Humanitarian Demining 2010". 27 - 29 April 2010, Šibenik, Croatia

10. Joels M, Pu Z, Wiegert O, Oitzl MS, Krugers HJ (2006): Learning under stress: how does it work? Trends Cogn. Sci. 10, 152-158.

11. Karst H, Berger S, Turiault M, Tronche F, Schutz G, Joëls M (2005): Mineralocorticoid receptors are indispensable for nongenomic modulation of hippocampal glutamate transmission by corticosterone. Proc. Natl. Acad. Sci. U.S.A. 102, 19204-19207.

12. Lefebrve D, Diederich C, Delcourt M, Giffroy JM (2007): The quality of the relation between handler and military dogs influences efficiency and welfare of dogs. Applied Animal Behavior Science, 104, 49-60.

13. Martin P, Bateson P (1993): Measuring behaviour. An introductory guide. 2nd Ed. Cambridge University Press, New York.

14. Overall KL (1997): Clinical behavioral medicine for small animals. Mosby - Year Book, St. Louis.

15. Overall KL, Dunham AE (2005): A protocol for predicting performance in military working dogs: roles for anxiety assessment and genetic markers. IWBDA 2005.wpd/doc.

16. Schenkel R (1967): Submission: its features and function in the wolf and dog. American Zoologist, 7, 319-329.

17. Schilder MBH, Van Der Borg JAM (2004): Training dogs with help of the shock collar: short and long term behavioural effects. Applied Animal Behaviour Science 85, 319-334.

18. Simpson MJA, Simpson AE (1977): One-zero and scan methods for sampling behaviour. Animal Behaviour, 25, 726-731.

19. Smeets T, Wolf OT, Giesbrecht T, Sijstermans K, Telgen S, Joëls M (2009): Stress selectively and lastingly promotes learning of context-related high arousing information. Psychoneuroendocrinology, 34(8), 1152-61.

20. Suen HK, Ary D (1984): Variables influencing one-zero and instantaneous time sampling outcomes. Primates, 25(1), 89-94. 
21. Svartberg K (2005): Breed-typical behaviour in dogs Historical remnants or recent constructs? Applied Animal Behaviour Science, 96, 293-313.

Geliş tarihi: 04.01.2012 / Kabul tarihi: 29.03.2012
Address for correspondence:

Dr. Yasemin Salgirli

Ankara Üniversitesi Veteriner Fakültesi

Fizyoloji Anabilim Dalı

06110 Dışkapı Ankara

E-posta: yaseminsalgirli@gmail.com 